\title{
Tidlige brukere av alkohol - hvem er de? Kjennetegn ved ungdom som starter tidlig med alkohol
}

\author{
Anders Grimsmo \\ Samfunnsmedisinsk forskningssenter Surnadal, Institutt for samfunnsmedisinske fag, \\ Norges teknisk-naturvitenskapelige universitet, 6650 Surnadal
}

\begin{abstract}
SAMMENDRAG
Debutalder med alkoholrus er en sterk prediktor for senere alkoholbruk. I denne undersøkelsen har vi sammenliknet de som starter med alkohol tidlig og før det er kulturelt akseptert, med ungdommene som begynner i konfirmasjonsalder og de som utsetter alkoholdebuten. Vi finner at gruppen som begynner tidlig ikke bare bryter de lokale tradisjonene for alkoholkonsum, men er i opposisjon til normer og autoriteter generelt. Alkohol er et positivt symbol for gruppen og det å ruse seg et rituale som gir mening i deres miljø. Hjemmet står i den sterkeste posisjonen til å kunne utsette ungdommens alkoholdebut. Vi skisserer hvilke implikasjoner dette bør ha for strategien i det forebyggende arbeidet.
\end{abstract}

\section{INNLEDNING}

Offentlig statistikk over alkoholforbruk plasserer Norge blant de land i den vestlige verden hvor alkoholforbruket er lavest (1). Helsemessige skader av alkohol ligger også lavere enn i andre land. Våre myndigheter mener likevel at alkoholskader utgjør et så stort problem at et redusert alkoholkonsum i befolkningen er høyt prioritert.

Alkoholforbruket i Norge har som i mange land vært knyttet til seremonier av ulike slag. Vår lutherske konfirmasjon er en religiøs seremoni, men representerte tidligere også en viktig markering av overgangen fra ungdom til voksen. Dette skjedde tidligere omlag ved 16 års alderen, og markerte i tillegg ofte starten på arbeidslivet. Naturlig nok ble dette også tidspunktet for når det ble kulturelt tillatt å bruke alkohol (2).

Konfirmasjonen som kulturell seremoni er blitt betydelig redusert ved at lengre utdanning har utsatt overgangen til det voksne samfunnet. Konfirmasjonstidspunktet er flyttet frem fordi det passer bedre med vårt offentlige utdanningssystem og skjer nå i 14-15 års alderen. Mens denne utviklingen har pågått, har myndighetene ført en streng alkoholpolitikk og har ikke tillatt at ungdom under 18 år får kjøpe alkohol. Akseptert debuttidspunkt for alkohol er i store deler av befolkningen likevel blitt hengende ved konfirmasjonen på tross av myndighetenes politikk og endring av tidspunkt og innhold i seremonien.

I undersøkelser som er gjennomført, blir det påpekt at tidlig debutalder for alkoholrus er vesentlig $\mathrm{i}$ utviklingen av et høyt alkoholkonsum $(3,4)$. Målsettingen med denne undersøkelsen har vært å se nærmere på hva som kjennetegner gruppen av ungdommer som starter tidlig å ruse seg på alkohol. Dette igjen har vi håpet skal styrke grunnlaget for et lokalt forebyggende arbeid.

Gruppen som vi her spesielt har studert, er ungdom i 14-15 års alderen som har hatt sin rusdebut med alkohol 13 år eller yngre, dvs. før det kulturelt er legalt, og som ruser seg regelmessig (en gang i måneden eller mer). Disse er sammenlignet med $\mathrm{de}$ som har hatt sin rusdebut ved konfirmasjonsalder (1415 år) og de som ennå ikke har ruset seg på alkohol i denne alderen. Vi har valgt å kalle gruppene henholdsvis normbryterne, konfirmantene og nølerne.

\section{MATERIALE OG METODE}

Fire årskull av skoleelever i tre kommuner ble valgt ut, svarende til 8. og 9. klasse i ungdomsskolen (1415 år) og 2. og 3. år i videregående (17-18 år). De fikk besvare et spørreskjema på skolen en fastlagt dato. Elever som var fraværende fra skolen denne dagen, fikk besvare spørsmålene et par dager senere. Elever som gikk på skole i andre kommuner og ungdom som ikke gikk på skole, fikk tilsendt skjemaet i posten. Det ble gjort to purringer på de utsendte skjemaene.

Spørreskjema inneholdt i alt 88 spørsmål. Rammen var det elevene kunne greie på en skoletime med lærer til stede. I hovedsak valgte vi å bruke spørsmål som Statens institutt for alkohol- og narkotikaforskning har brukt i sine undersøkelser tidligere. Det gjorde vi for å kunne sammenligne og for å spare arbeid med hensyn til utformingen. Vi prøvde først spørreskjemaet i en skoleklasse som ikke skulle være med i undersøkelsen.

741 ungdommer var med i utvalget. 707 skjemaer ble besvart. Fem skjemaer var ufullstendig utfylt og ble forkastet. $702(94 \%)$ skjemaer ble med i bearbei- 
delsen. Frafallet var ikke knyttet til kjønn, alder eller bosted.

Til å beregne alkoholkonsumet benyttet vi samme metode som Statens institutt for alkohol- og narkotikaforskning (5). Mengde øl, vin og brennevin ble omregnet til mengde ren alkohol per år basert på siste fire ukers konsum. Antall ganger man har drukket denne perioden ble multiplisert med kvantumet man drakk siste gang. Vi benyttet statistikkprogrammet FOSS i feilsøking og bearbeidelse av dataene (6). Ved sammenlikning av gjennomsnittlig alkoholkonsum mellom grupper brukte vi enkel variansanalyse (Ftest) og $\chi 2$-test ved sammenlikning av gruppenes fordeling på utfallene. De forskjellene som vi har påpekt, hadde en p-verdi under 0,05 .

I den trinnvise multiple regresjonsanalysen er de uavhengige variablene valgt ut etter relevans og grad av bivariat sammenheng med den avhengige variabelen. Det var i utgangspunktet mange variabler. Vi fant det derfor praktisk å slå flere av dem sammen ved å lage indekser, blant annet basert på en komponentanalyse. Forklaringsvariablenes utfall er beskrevet $\mathrm{i}$ en tidligere artikkel (7).

Vi undersøkte om variablene og indeksene hadde en tilnærmet lineær sammenheng med den avhengige variabelen. Vi har vurdert graden av interaksjon mellom de uavhengige variablene. Noen av variablene ble omgjort til såkalte «dummy-variable». Den avhengige variabelen er en slik «dummy-variabel» (8).

\section{RESULTATER}

Tabell 1 viser hvor sterk sammenheng det var mellom alder for første alkoholrus og årlig konsum av alkohol ved 17-18 års alder, omregnet til antall liter ren alkohol. Gjennomsnittlig årlig alkoholkonsum i denne alderen var 4,8 liter.

Tabell 1. Årlig konsum av alkohol omregnet til liter ren alkohol $\mathrm{i}$ aldersgruppen 17-18 år, knyttet til debutalder for første alkoholrus.

\begin{tabular}{cccc}
\hline $\begin{array}{c}\text { Alder for første } \\
\text { alkoholrus }\end{array}$ & $\begin{array}{c}\text { Antall } \\
\text { personer }\end{array}$ & $\begin{array}{c}\text { Liter } \\
\text { per år }\end{array}$ & P-verdi \\
\hline$<12$ år & 10 & 18,1 & 0,0000 \\
13 år & 20 & 10,1 & \\
14 år & 52 & 6,2 & \\
15 år & 105 & 5,8 & \\
16 år & 58 & 5,4 & \\
17 år & 18 & 2,2 & \\
18 år & 4 & 0,9 & \\
Aldri & 63 & 0,2 & \\
\hline
\end{tabular}

I aldersgruppen 14-15 år var gjennomsnittsforbruket 2,3 liter ren alkohol per år. Gutter og jenter drakk like mye. I vårt materiale var det 312 ungdommer i denne alderen. $79 \%$ av disse hadde drukket alkohol. $48 \%$ hadde vært beruset minst en gang. 44 ungdommer i alderen 14-15 år (14\%) beruset seg regelmessig og hadde begynt med dette før de ble 14 år. Det er disse vi har kalt normbryterne og som vi har sammenliknet med konfirmantene (de som debuterte med alkohol ved konfirmasjonsalder, 33\%) og nølerne (de som ennå ikke hadde begynt med alkohol, 53\%).

\section{Sosiokulturell bakgrunn}

De som ikke hadde begynt å drikke, nølerne, kom i større grad fra lavurbaniserte områder enn de andre (Tabell 2). Normbrytergruppen oppfattet stedlig holdning til alkohol på offentlige fester og tilstelninger som mer liberal enn de andre gruppene. Når det gjaldt forhold i hjemmet, var det foreldrenes holdning til alkohol som hadde sterkest sammenheng med hvilken gruppe ungdommen tilhørte.

De som hadde debutert tidligst med alkohol, normbryterne, hadde i langt større grad enn andre venner som drakk, og de kom tydeligvis oftere fra et miljø med kriminalitet og narkotika.

\section{Tilgang på alkohol}

Omsetning av alkohol til ungdom under 18 år er ulovlig i Norge. Tabell 3 viser at halvparten likevel sa at det er lett å få kjøpt alkohol i butikk for dem under 18 år. For normbryterne var det omtrent like lett å få kjøpt hjemmebrent på det illegale markedet. De kjøpte vanligvis alkohol i større omfang enn de fikk alkohol og i større grad enn konfirmantene. Vanligst er det å få mellommenn til å handle alkohol.

Tabell 3. Mulighetene til å skaffe alkohol for de som hadde begynt å bruke alkohol inndelt etter når de begynte å ruse seg på alkohol ( $\leq 13$ år = normbryterne, $14-15$ år = konfirmantene $)$ Antall personer og prosent av gruppen.

\begin{tabular}{lrrrrr}
\hline \multirow{2}{*}{ Kilde } & Normbryterne & \multicolumn{3}{c}{ Konfirmantene } \\
& $\mathrm{n}$ & $\%$ & $\mathrm{n}$ & $\%$ & $\mathrm{p}$-verdi \\
\hline Kjøper øl lett i butikk & 22 & $50 \%$ & 47 & $46 \%$ & 0,799 \\
Kjøper hjemmebrent & 21 & $48 \%$ & 27 & $27 \%$ & 0,037 \\
Får andre til å kjøpe & 27 & $61 \%$ & 36 & $35 \%$ & 0.007 \\
Får av foreldre & 3 & $7 \%$ & 14 & $14 \%$ & 0,137 \\
Får av andre voksne & 18 & $41 \%$ & 45 & $44 \%$ & 0,236 \\
Får av venner & 11 & $25 \%$ & 29 & $28 \%$ & 0,190 \\
Stjeler hjemme & 6 & $14 \%$ & 18 & $18 \%$ & 0,176 \\
\hline Antall i gruppen & 44 & \multicolumn{5}{c}{102} \\
\hline
\end{tabular}

En del av ungdommen fikk vanligvis alkohol med seg hjemmefra, men enda flere skaffet seg alkohol ved å ta hjemme. Ungdommen fikk hyppigere servert alkohol av voksne enn av venner. $60 \%$ av ungdommen oppga at de vanligste arenaene for drikking var offentlige tilstelninger og privatfester. Det var bare $5 \%$ som sa at de drakk alkohol sammen med familien.

\section{Personlighet og sosiale preferanser}

Det var ingen forskjell mellom gruppene mht. oppgitte prestasjoner på skolen og fremtidsplaner i skolesammenheng. Men tabell 4 viser at nølerne trivdes bedre i skolen enn normbryterne og konfirmantene. 
Tabell 2. Andel fra ulike sosiale og kulturelle forhold blant grupper av ungdom 14-15 år gamle, inndelt etter når de begynte å ruse seg på alkohol $(\leq 13$ år = normbryterne, $14-15$ år = konfirmantene, ikke begynt $=$ nølerne $)$. Antall personer og prosent av gruppen.

\begin{tabular}{lrrrrrrr}
\hline & \multicolumn{2}{c}{ Normbryterne } & \multicolumn{2}{c}{ Konfirmantene } & \multicolumn{2}{c}{ Nølerne } & p-verdi \\
\hline Sosiokulturell bakgrunn & $\mathrm{n}$ & \multicolumn{1}{c}{$\%$} & $\mathrm{n}$ & $\%$ & $\mathrm{n}$ & $\%$ & $\mathrm{p}$ \\
\hline Fra lavurbanisert område & 13 & $30 \%$ & 28 & $28 \%$ & 76 & $46 \%$ & 0,006 \\
Liberal offentlig ruspolitikk & 24 & $55 \%$ & 45 & $44 \%$ & 31 & $19 \%$ & $<0,001$ \\
Far uten arbeid & 4 & $9 \%$ & 4 & $4 \%$ & 9 & $5 \%$ & 0,127 \\
Skilte foreldre & 11 & $25 \%$ & 22 & $22 \%$ & 17 & $10 \%$ & 0,011 \\
Foreldre liberale til alkohol & 14 & $32 \%$ & 23 & $23 \%$ & 13 & $8 \%$ & $<0,001$ \\
To bestevenner som drikker & 17 & $39 \%$ & 10 & $10 \%$ & 1 & $1 \%$ & $<0,001$ \\
Kriminalitet blant venner & 16 & $36 \%$ & 17 & $17 \%$ & 9 & $5 \%$ & $<0,001$ \\
Venner bruker narkotika & 5 & $11 \%$ & 2 & $2 \%$ & 1 & $1 \%$ & 0,005 \\
\hline Antall i gruppen & 44 & \multicolumn{7}{c}{102} & 166 & & \\
\hline
\end{tabular}

Tabell 4. Ulikheter mht. personlighet og sosiale preferanser mellom grupper av ungdom 14-15 år gamle, inndelt etter når de begynte å ruse seg på alkohol $(\leq 13$ år = normbryterne, $14-15$ år = konfirmantene, ikke begynt = nølerne $)$. Antall personer og prosent av gruppen.

\begin{tabular}{lrrrrrrr}
\hline & \multicolumn{2}{c}{ Normbryterne } & \multicolumn{2}{c}{ Konfirmantene } & \multicolumn{2}{c}{ Nølerne } & \\
& $\mathrm{n}$ & \multicolumn{1}{c}{$\%$} & $\mathrm{n}$ & \multicolumn{1}{c}{ \% } & $\mathrm{n}$ & \multicolumn{1}{c}{$\%$} & $\mathrm{p}$-verdi \\
\hline Trives svært godt i skolen & 6 & $14 \%$ & 16 & $16 \%$ & 61 & $37 \%$ & $<0,001$ \\
Svært god eller god selvtillit & 15 & $34 \%$ & 57 & $56 \%$ & 115 & $69 \%$ & $<0,001$ \\
Frykt for arbeidsledighet & 21 & $48 \%$ & 30 & $29 \%$ & 31 & $19 \%$ & 0,005 \\
Personlig kristen & 0 & $0 \%$ & 5 & $5 \%$ & 13 & $8 \%$ & 0,050 \\
Videofilm Ú1 gang per uke & 28 & $64 \%$ & 50 & $49 \%$ & 43 & $26 \%$ & $<0,001$ \\
Ofte ute med kamerater & 35 & $80 \%$ & 58 & $57 \%$ & 71 & $43 \%$ & $<0,001$ \\
Mye tid med familien & 13 & $30 \%$ & 39 & $38 \%$ & 103 & $62 \%$ & $<0,001$ \\
\hline Antall i gruppen & 44 & 102 & & 166 & & \\
\hline
\end{tabular}

Det var ingen vesentlig forskjell mellom gruppene mht. samlet angstnivå. Kun frykten for arbeidsledighet var signifikant forskjellig. Normbryterne var mest bekymret. De tilkjennegir også minst selvtillit. Ingen av normbryterne oppga å være personlig kristne.

For uorganiserte fritidsaktiviteter skilte normbryterne seg ut med mer tid brukt på videofilmer, være ute med kamerater og lytte på musikk. Nølerne på sin side foretrakk langt mer å være hjemme med familien. Det var ingen forskjell mht. TV-titting, avislesning og tid sammen med kamerater hjemme.

Samlet sett deltok gruppene omtrent likt i det organiserte fritidstilbudet - sport, foreningsliv etc., men normbryterne og konfirmantene hadde en viss preferanse for fritidsklubbaktiviteter.

\section{Atferdstrekk}

Tabell 5 viser at normbryterne i større grad enn andre brøt grenser også på områder som ikke gjaldt alkohol. Laveste aldersgrense for bruk av motorkjøretøy er 16 år. Mange hadde kjørt yngre enn dette, men vel $40 \%$ av normbryterne hadde også kjørt i beruset tilstand før de ble 16 år. Normbryterne skaffet seg sin «bevegelsesfrihet» ved at de i større grad enn andre skulket skolen og var borte om natta på andre steder enn det foreldrene trodde de var.

Tidlig høyt forbruk av alkohol var også forbundet med tidlig eller økt bruk av andre nytelsesmidler som kaffe, tobakk og «godterier» (potetgull, brus etc.). Relevant for denne sammenhengen fant vi også at normbryterne i gjennomsnitt disponerte mer penger enn de andre ungdommene. De fikk mer penger av sine foreldre og de skaffet seg mer på egen hånd.

\section{Holdning til alkohol}

Normbryterne hadde en langt mer liberal holdning til omgang med alkohol enn konfirmantene, som igjen var mer liberal enn nølerne. Jevnt over halvparten av normbryterne sa seg enig $\mathrm{i}$ at ungdom burde få seg servert alkohol av foreldrene ved festlige anledninger hjemme, til måltider eller for å ha med seg ut. Mindre enn 5\% av nølerne var enig i det samme.

På spørsmål om hvorfor normbryterne og konfirmantene selv drakk alkohol, anga normbryterne at det er artig å være full (64\%) og fest og alkohol hører sammen (59\%) som viktigste årsak. Det var færre av konfirmantene som oppga dette (henholdsvis 30\% og $37 \%$ ). Deres hyppigste begrunnelse var at det ble lettere å komme i kontakt med andre (40\%). 
Tabell 5. Ulike atferdstrekk knyttet til grupper av ungdom 14-15 år gamle, inndelt etter når de begynte å ruse seg på alkohol $(\leq 13 \mathrm{år}=$ normbryterne, $14-15$ år = konfirmantene, ikke begynt = nølerne $)$. Antall personer og prosent av gruppen.

\begin{tabular}{|c|c|c|c|c|c|c|c|}
\hline & \multicolumn{2}{|c|}{ Normbryterne } & \multicolumn{2}{|c|}{ Konfirmantene } & \multicolumn{2}{|c|}{ Nølerne } & \multirow[b]{2}{*}{ p-verdi } \\
\hline & $\mathrm{n}$ & $\%$ & $\mathrm{n}$ & $\%$ & $\mathrm{n}$ & $\%$ & \\
\hline Skulker skolen iblant & 15 & $34 \%$ & 18 & $18 \%$ & 6 & $4 \%$ & $<0,001$ \\
\hline Iblant borte om natta uten at foreldre egentlig vet hvor & 9 & $21 \%$ & 16 & $16 \%$ & 12 & $7 \%$ & $<0,001$ \\
\hline En eller flere ganger kjørt moped/motorsykkel beruset & 18 & $41 \%$ & 16 & $16 \%$ & 5 & $3 \%$ & $<0,001$ \\
\hline Vært i kontakt med politiet & 7 & $16 \%$ & 2 & $2 \%$ & 5 & $3 \%$ & $<0,001$ \\
\hline Røyker daglig & 18 & $41 \%$ & 21 & $21 \%$ & 3 & $2 \%$ & $<0,001$ \\
\hline Drikker kaffe/te daglig & 7 & $16 \%$ & 8 & $8 \%$ & 4 & $2 \%$ & $<0,001$ \\
\hline Spiser «godterier» daglig eller nesten daglig & 20 & $45 \%$ & 33 & $32 \%$ & 25 & $15 \%$ & $<0,001$ \\
\hline Antall i gruppen & 44 & & 102 & & 166 & & \\
\hline
\end{tabular}

Tabell 6. Årsaker til at andre ungdommer drikker angitt av grupper av ungdom 14-15 år gamle, inndelt etter når de begynte å ruse seg på alkohol $(\leq 13$ år = normbryterne, 14-15 år = konfirmantene, ikke begynt = nølerne). Antall personer og prosent av gruppen.

\begin{tabular}{|c|c|c|c|c|c|c|c|}
\hline & \multicolumn{2}{|c|}{ Normbryterne } & \multicolumn{2}{|c|}{ Konfirmantene } & \multicolumn{2}{|c|}{ Nølerne } & \multirow[b]{2}{*}{ p-verdi } \\
\hline & $\mathrm{n}$ & $\%$ & $\mathrm{n}$ & $\%$ & $\mathrm{n}$ & $\%$ & \\
\hline Får lettere kontakt med andre & 22 & $50 \%$ & 53 & $52 \%$ & 62 & $37 \%$ & $<0,001$ \\
\hline Vennene deres drikker & 21 & $48 \%$ & 54 & $53 \%$ & 99 & $60 \%$ & $<0,001$ \\
\hline De liker smaken & 9 & $21 \%$ & 21 & $21 \%$ & 20 & $12 \%$ & 0,003 \\
\hline Alkohol og fest hører sammen & 26 & $59 \%$ & 45 & $44 \%$ & 54 & $33 \%$ & $<0,001$ \\
\hline Artig å være full & 31 & $71 \%$ & 49 & $48 \%$ & 79 & $48 \%$ & $<0,001$ \\
\hline Foreldrene drikker & 1 & $2 \%$ & 2 & $2 \%$ & 16 & $10 \%$ & 0,041 \\
\hline Det er vanskelig å si nei & 9 & $21 \%$ & 22 & $22 \%$ & 64 & $39 \%$ & $<0,001$ \\
\hline De føler seg ensom & 2 & $5 \%$ & 5 & $5 \%$ & 14 & $8 \%$ & 0,072 \\
\hline Ubesvart & 0 & $0 \%$ & 2 & $2 \%$ & 3 & $2 \%$ & 0,356 \\
\hline Antall i gruppen & 44 & & 102 & & 166 & & \\
\hline
\end{tabular}

Tabell 6 viser hva ungdommen trodde var viktigste årsaker til at andre drakk (de kunne krysse av tre alternativer). Nølerne skilte seg fra de andre med at de i mindre grad trodde det skyldtes at det blir lettere å få kontakt med andre og at det var smaken, men heller fordi vennene drikker og at det er vanskelig å si nei. Normbryterne tror i langt større grad enn de andre at gleden ved rusen er den viktigste årsak til at ungdommer drikker, faktisk i større grad for andre enn for seg selv. De angir også at man får lettere kontakt med andre er viktigere for andre enn for seg selv.

\section{Multivariat analyse}

Tabell 7 viser resultatet av en multippel regresjonsanalyse av de viktigste faktorene som har en bivariat sammenheng med ungdommens forhold til alkohol. I denne analysen er avhengig variabel normbryterne $=$ $1 \mathrm{og}$ andre (konfirmantene og nølerne) $=0$.

Den bivariate sammenhengen ble naturlig nok mindre i regresjonsanalysen, men alle variable unntatt kjønn, skilte foreldre og personlig kristen forble statistisk signifikante.

Bestevenner som drikker mye fremstår i regresjonsanalysen som den variabelen som hadde størst sammenheng med det å tilhøre normbrytergruppen, likeledes kriminalitet blant venner eller det å ha lav selvtillit. Skulking i skolen var også et viktig atferdstrekk ved gruppen, selv om betydningen blir halvert $i$ regresjonsanalysen. Betydningen av liberal offentlig alkoholpolitikk og røyking reduseres også betydelig i regresjonsanalysen.

\section{DISKUSJON}

Vi har i denne analysen sett på faktorer som kan ha tilknytning til alkoholforbruket og undersøkt forholdene $\mathrm{i}$ den alderen flertallet av ungdommen begynner å drikke (14-15 år). Ved å utelate 17-18 åringene reduserte vi betydningen av tilpasninger som kommer sekundært til et etablert forhold til alkohol.

$\mathrm{Vi}$ valgte å dele ungdommen i tre grupper knyttet til det som har vært de kulturelle normene for alkoholdebut i Norge. Tabell 1 viser at alkoholkonsumet ikke bare er relatert til debutalder, men at debutalder også er tilnærmet normalfordelt omkring alderen for da de fleste blir konfirmert. Selv om tidspunkt og innhold i konfirmasjonsseremonien er endret de senere år, så er de kulturelle bindingene mellom seremonien og alkohol bevart, og sterkere enn det en streng alkohollovgivning og helseopplysning har maktet å hanskes med i samme tidsrom. 
Tabell 7. Multippel regresjonsanalyse av faktorer som har sammenheng med når ungdom begynte å ruse seg på alkohol $(\leq 13$ år = 1, 14-15 år eller har ikke begynt =0)

\begin{tabular}{|c|c|c|c|}
\hline & $\begin{array}{c}\text { Pearsons korrelasjons- } \\
\text { koeffisient }\end{array}$ & $\begin{array}{l}\text { Multippel regresjons- } \\
\text { koeffisient }\end{array}$ & p-verdi \\
\hline \multicolumn{4}{|l|}{ Sosiokulturell bakgrunn } \\
\hline Er jente & 0,035 & 0,006 & 0,557 \\
\hline Fra lavurbanisert område & $-0,060$ & $-0,063$ & $<0,001$ \\
\hline Liberal offentlig ruspolitikk & 0,242 & 0,104 & $<0,001$ \\
\hline Skilte foreldre & 0,085 & 0,009 & 0,499 \\
\hline Mengde alkohol far drikker & 0,046 & 0,040 & 0,025 \\
\hline Foreldre liberale til alkohol & 0,210 & 0,100 & $<0,001$ \\
\hline To bestevenner som drikker & 0,386 & 0,280 & $<0,001$ \\
\hline Kriminalitet blant venner & 0,280 & 0,134 & $<0,001$ \\
\hline \multicolumn{4}{|l|}{ Tilgang på alkohol } \\
\hline Penger disponibelt & 0,195 & 0,073 & $<0,001$ \\
\hline Får alkohol av foreldre & 0,131 & 0,076 & $<0,001$ \\
\hline \multicolumn{4}{|l|}{ Personlighet og sosiale preferanser } \\
\hline Trives godt $\mathrm{i}$ skolen & $-0,105$ & $-0,063$ & $<0,001$ \\
\hline Svært god eller god selvtillit & $-0,157$ & $-0,116$ & $<0,001$ \\
\hline Personlig kristen & $-0,105$ & $-0,028$ & 0,148 \\
\hline Videofilm Ú1 gang per uke & 0,171 & 0,085 & $<0,001$ \\
\hline Ofte ute med kamerater & 0,214 & 0,101 & $<0,001$ \\
\hline \multicolumn{4}{|l|}{ Atferdstrekk } \\
\hline Skulker skolen iblant & 0,272 & 0,113 & $<0,001$ \\
\hline Iblant borte om natta uten at foreldre vet hvor & 0,149 & 0,076 & $<0,001$ \\
\hline Vært i kontakt med politiet & 0,219 & 0,091 & $<0,001$ \\
\hline Røyker daglig & 0,390 & 0,124 & $<0,001$ \\
\hline Spiser «godterier» daglig eller nesten daglig & 0,155 & 0,082 & $<0,001$ \\
\hline \multicolumn{4}{|l|}{ Egen holdning } \\
\hline Liberal holdning til alkohol & 0,184 & 0,078 & $<0,001$ \\
\hline
\end{tabular}

Forklart varians: $\mathrm{R}^{2}=28,6 \%$

Tradisjonenes og normenes styrke til tross, så kontrollerer heller ikke de alkoholvanene i befolkningen helt. Omlag $14 \%$ av ungdommene debuterte med alkoholrus før det kulturelt er akseptert (13 år eller yngre). Det alkoholkonsumet denne gruppen etter hvert etablerer, setter dem i stor fare for alkoholrelaterte problemer, som ungdom i forhold til ulykker og vold, og som voksne med andre problemer i tillegg.

Vi valgte å kalle gruppen av tidligere alkoholbrukere for normbrytere i relasjon til deres alkoholdebut. Analysen viser at normbryting i denne gruppen var generell. Denne gruppen brøt også normer i forhold til myndighetene (kriminalitet), skolen (skulk) og tradisjoner for konsum (tobakk og kaffe og forbruk av «godterier») i større grad enn de andre. Selv om de kom fra hjem som var liberale, gikk de også utover de grensene som foreldrene hadde satt, f.eks. med å være borte om natta uten at foreldrene visste hvor og ved å stjele alkohol hjemme. Det har vært vanlig å trekke den konklusjonen at det er et høyt alkoholforbruk som fører til slik atferd, men det er i studier av elever i barneskolen blitt vist at den normbrytende atferden kan identifiseres før de begynner med alkohol (9).

Normbrytergruppen uttrykte at de hadde lavere selvtillit enn de andre. Umiddelbart kan dette synes å stå $i$ en viss motsetning til en atferd som er utprøvende og avviker fra samfunnets normer. Likeledes at ungdommene i normbrytergruppen oppga også å ha flere venner.

Svarene på våre spørsmål tyder på at normbrytergruppen foretrakk miljøer og aktiviteter som stilte små krav til å innrette seg etter autoriteter og regler. De foretrakk fritidsaktiviteter som er lite styrt av voksne (se video, kafebesøk og fritidsklubber, i motsetning til organisert idrett og organisasjonsliv) og trivdes dårligere i skolen. De brukte mer tid sammen med venner enn de andre.

For ungdom med lav selvtillit kan krav være en trussel for selvaktelsen. For å beskytte selvaktelsen vil disse ungdommene forsøke å devaluere samfunnets vanlige normer. Ved å søke sammen med andre som opplever det samme, kan dette kompenseres gjennom å oppleve gruppetilhørighet, og det åpner for dannelsen av subkulturer med egne regler og holdninger. Det å kunne vise dristighet og protest overfor samfunnets autoriteter og normer blir gjerne en del av verdiene $\mathrm{i}$ slike grupper. $\AA$ begynne med alkohol før det er legalt, fungerer slik, også langt utover det miljøet de selv tilhører. Dessuten har alkohol den dobbelteffekten at dristigheten øker under ruspåvirkningen. 
Når normbrytergruppen svarer på spørsmålene om hvorfor ungdom bruker alkohol, tilkjennegir de en langt mer positive holdning til alkohol enn de andre. Alkohol blir et positivt symbol for gruppen og det å ruse seg et rituale som skaper mening på samme måte som for voksne ved festlige sammenkomster ved å øke fellesskapsfølelsen, oppleve glede og sette til side grenser og normer som finnes i hverdagen (10).

I forebyggende sammenheng er gruppen som utsetter sin alkoholdebut interessant. På en måte bryter også nølerne de lokale alkoholtradisjonene. De skiller seg sterkest ut fra både normbryterne og konfirmantene vedrørende tilknytningen til hjemmet (Tabell 4). De tilbringer mye tid hjemme og man må derfor kunne anta at de i større grad følger hjemmets eller de voksnes normer for alkoholkonsum blant ungdom. De kom hyppig fra hjem som har en strengere holdning til alkohol, som ikke delte ut alkohol til ungdommene og som utøvde en sterkere kontroll av ungdommenes aktiviteter. Dette viser at hjemmet kan gi ungdommen styrke til å avvike fra det som måtte være de kulturelle strømningene i samfunnet.

Bruk av alkohol har også opprinnelig i stor grad vært knyttet til viktige overgangsfaser i livet (konfirmasjon, bryllup, etc.) og sammenkomster. Ved slike anledninger har det vært vanlig at alle generasjonene har deltatt, både voksne og unge, og på den måten har også fellesskapet kunnet kontrollere alkoholbruken (11). Nølerne kom i større grad fra lavurbaniserte områder (Tabell 2), hvor slike tradisjoner fortsatt er i hevd. I mer urbaniserte områder har de voksne sluttet å delta på mange av de offentlige tilstelningene hvor alkoholrus har vært vanlig. Derved har flere av fellesskapets kontrollmekanismer også forsvunnet. Indirekte ser vi også dette i hva de tre gruppene av ungdommer svarer på spørsmålet om de opplever offentlig ruspolitikk som restriktiv (Tabell 2).

\section{KONKLUSJON}

Debutalder for alkoholrus er en viktig prediktor for alkoholkonsumet blant ungdom. Vi finner i denne undersøkelsen at lokale tradisjoner har størst innflytelse på debutalder. Det er hjemmet og voksnes tilstedeværelse som kan sette rammene for ungdomsmiljøene og som evt. er i posisjon til å endre debutalder (12). Offentlige reguleringer gjennom lovverk og salgsrestriksjoner er av langt mindre betydning også i et land som Norge som har tradisjoner for offentlige reguleringer.

Helsepersonell er i ungdommers øyne representanter for autoritetene. Overfor gruppen som debuterer tidlig vil tradisjonell helseopplysning derfor virke mot sin hensikt (13). Forebyggende arbeid blant ungdom med problemer må skje gjennom involvering, og første steg må være å fokusere på å styrke deres selvaktelse, dvs. redusere deres behov for å danne eget fellesskap utenfor majoriteten av ungdomsfellesskapet. Lojaliteten de viser overfor egne må sees som et positivt trekk og kan være en plattform for opparbeidelse av ansvarsfølelse. Det er i en kontekst hvor man opplever egenverd, ansvar og lojalitet overfor egne at man eventuelt kan være villig til å reflektere over alkoholens negative virkninger i eget miljø.

\section{REFERANSER}

1. Grytten L, Nordlund S, Hauge R, Hoel I. Alcohol and drugs in Norway 1995. Oslo: The National Institute for Alchol and Drug Research, 1995.

2. Douglas M. Constructive drinking. Perspectives on drink from anthropology. Cambrigde: Cambrigde University Press, 1987.

3. Chou SP, Pickering RP. Early onset of drinking as a risk factor for lifetime alcohol-related problems. $\mathrm{Br} J$ Addict 1992; 87: 1199-1204.

4. Pedersen W, Aas H. Full for første gang; en longitudinell studie. Nordisk Alkoholtidsskrift 1995; 3: 121-131.

5. Nordlund S. Metoder og metodeproblemer ved estimering av alkoholforbruk. Oslo: Statens institutt for alkohol- og narkotikaforskning, 1992.

6. Amundsen A. FOSS. Fil-orientert-statistikk-system for MS-Dos og UNIX-maskiner. Oslo: Statens institutt for alkohol- og narkotikaforskning, 1993.

7. Grimsmo A, Storset B, Ødegård A. Utvikling av alkoholvaner blant ungdom. Tidsskr Nor Lageforen 1995; 115: 2764-2768.

8. Saglie J. Norske drikkekulturer. Geografi, sosial bakgrunn, livsstil og tilgjengelighet. SIFA rapport nr. 1/94. Oslo: Statens institutt for alkohol- og narkotikaforskning, 1994.

9. Tell GS. Epidemiology and prevention of chronic disease and risk factors in adolescents: The Oslo youth study. Oslo: Institute for Hygiene, University of Oslo, 1987.

10. Cohen A. The symbolic construction of community. London: Routlegde, 1985.

11. Gefou-Madianou D. Alcohol, gender and culture. London: Routledge, 1992.

12. Cohen DA, Richardson J, LaBree L. Parenting behaviors and the onset of smoking and alcohol use: a longitudinal study. Pediatrics 1994; 94: 368-75.

13. Moskowitz JM. The primary prevention of alchol problems: a critical review of the research litterature. $J$ Stud Alcohol 1989; 50: 54-88. 